along the dry beds of rivers, but frequent storms, which in Jehol turned scorching summer to bitter cold, often delayed or prevented a projected tour. "A proverb goes 'a precipice in front, a wolf behind' ; when our march was impeded, we could not safely stay where we were because of there being a danger of bandits' assault". The expedition's work was done under escort of thirty soldiers and occasionally under additional protection from garrisons.

Dirty and scarce drinking water, and "horribly poisonous insects", with the concomitant troubles of dysentery, trachoma, etc., were probably greater difficulties than the bandits, who only fired upon a camp on one occasion. An endemic epidemic goitre was found to be widespread in south-western Jehol.

The preliminary scientific results are summarised by the head of each section in the first general report (October 1934). A brief stratigraphical summary reports abundant fossil Lycoptera and many fossil insect larvæ (Ephemeropsis) in lower Cretaceous rocks. In loess strata of Middle Pleistocene age, remains of Ovis and Elephas included bone pieces apparently engraved by ancient man. Jehol was a nomad zone originally occupied by Mongolians ; during the Shin dynasty, these Mongolians had declined in prosperity and the Hans (Chinese in the Han dynasty) emigrated there. In the northern district of Manchoukuo the Mongolians still predominate, and throughout the country three systems of farming can be traced, the North Chinese, Manchurian and Mongolian. The animals found still recall the forests, which have been ruthlessly despoiled since the Hans. The November report (Section 4, Part 1) figures and describes eight species of new woody plants (by Dr. T. Nakai) and twenty-nine new herbaceous plants (by Dr. T. Nakai and M. Kitagawa).

Section 5, part 1, consists of an account of the freshwater fishes of the province of Jehol. This province-a highland area occupying the southwestern part of Manchoukuo and contiguous with the north-eastern border of the Chinese province of Hopei (Chili)-is irrigated by the upper reaches of several rivers in the waters of which and those of associated lakes and ponds $\mathbf{7 8 3}$ fishes were collected. These comprised 33 species and one sub-species representative of the two families Cyprinidæ and Ophicephalidæ. The detailed taxonomic descriptions are accompanied by twenty-one beautifully produced plates in which all the species are carefully figured, some of them in colour.

\section{Lubricating Value of Mineral Oils}

$\mathrm{I}^{\mathrm{N}}$ 1929, under the auspices of the Department of Scientific and Industrial Research, a paper (Lubrication Research, Technical Paper No. 1) by the late Sir William Hardy and M. E. Nottage on the analysis of commercial lubricating oils by physical methods was prepared. It was considered, however, inadvisable to draw conclusions from the results of experiments reported therein, since only two oils, and those of unknown origin, had been employed. A further paper by Miss Nottage recently published under similar conditions (Lubrication Research, Technical Paper No. 2. London: H.M. Stationery Office. 9d. net) entitled "A Study of the Boundary Lubricating Value of Mineral Oils of Different Origin" is intended in certain respects to supplement the original one.

When the film of lubricating oil separating two smooth bearing surfaces is so thin that no part of it is beyond the range of cohesive forces of attraction transmittable from these surfaces, boundary conditions are said to prevail. Interposition between the two surfaces of a film of oil may, to some extent, neutralise these conditions or, in other words, boundary lubrication may be employed. In these circumstances two important factors must be taken into consideration: the effect of the surface on the oil, hence the nature of the bearing surface, since chemical activity occurring at an interface differs materially from that occurring in bulk; and chemical properties of the lubricant, the function of which of neutralising the cohesive forces of attraction is effected by the formation of adsorptive layers on the bearing surfaces.

Inasmuch as mineral lubricating oils consist of inactive, non-polar constituents and surface-active polar constituents, from which the greater part of the adsorptive layer is formed, the properties of the film may differ considerably from properties of the oil in bulk. Important factors determining frictionreducing properties of the adsorptive layer are the chemical nature of the constituents and their degree of dispersion. This, in turn, may be varied by changes of temperature, the presence of other substances which play no part in reducing friction, or the solution of oil in certain volatile solvents.

Having regard to the important part played by wax in mineral oils, concurrent investigations were made to obtain some indication of its rôle in a lubricant under boundary conditions. It is shown that, in spite of the general view that wax is detrimental to a lubricant, it does, in certain cases, enhance the lubricating value of the oil at the boundary layer.

\section{University and Educational Intelligence}

Cambridge.-At St. John's College a research studentship and research exhibitions are offered for competition in July 1935. One Strathcona research studentship of the annual value of $£ 150$ is offered for competition among research students who are graduates of any university other than Cambridge. Two Strathcona exhibitions of the annual value of $£ 40$ are also offered for competition under the same conditions as the studentship.

Grants from the Worts Fund have been made as follows :- $£ 75$ to D. B. Keith, A. B. Whatman, and J. W. Wright towards the expenses of an expedition to survey the north coast of North-East Land (Spitsbergen); £120 to P. T. Cotton, D. W. Ewer and L. E. R. Picken towards the expenses of an expedition to investigate the freshwater ecology of the southwest Balkans; $£ 50$ to T. T. Paterson towards the expenses of an expedition to the North-West Frontier of India for the purpose of studying quaternary deposits; $£ 2610 s$. to J. R. B. Stewart for archæological investigations in Asia Minor ; £25 to Dr. T. C. Phemister towards the expenses of a geological and petrological survey of the Coast Range batholith of British Columbia; $£ 25$ to T. G. Tutin for a visit to the Mediterranean coast of Spain to study the destruction of the eel-grass, Zostera marina; $£ 25$ to K. H. Chapman for an expedition to Morocco to study the Moroccan locust, Dociostaurus morocannus.

J. H. Lockhead, of Christ's College, has been nominated to use the University's table at the Zoological Station at Naples. 